\title{
THE SOCIAL FUNCTION OF PROPERTY OWNERSHIP IN THE CONTEXT OF SUSTAINABLE DEVELOPMENT ${ }^{* * *}$
}

\begin{abstract}
The subject matter of this paper is the constitutionalization of the right to property in the comparative constitutionalism, within the context of sustainable development, as a long-term prospective of a community existence and advancement. The first part of the paper points out to social and ecological functions of camu and considers, from the comparative perspective, the constitutional guarantees on the right to property, the forms of property ownership, and the title holders of property rights. The second part is devoted to constitutional solutions related to the regime of using the natural (developmental) resources, through the prism of the social function of property ownership, the public interest and the environment protection. The authors also discuss the legislative authority allocation in this field of proprietary relations between the various levels of authority in federal and regionally organized states. The third part of the paper provides a comparative analysis of the conditions for expropriation permissibility and limitations to property rights.
\end{abstract}

Keywords: the Constitution, right to property, social function of property ownership, ecological function of property ownership, limitations to property rights, sustainable development.

\footnotetext{
*marijana.pajvancic@gmail.com

nevena@prafak.ni.ac.rs

${ }^{* *}$ The contribution of the co-author Nevena Petrušić is the result of her engagement in the Project no. 179046: Protection of Human and Minority Rights in the European Legal Space, financed by the Ministry of Education, Science and Technological Development of the Republic of Serbia.

${ }^{* * *}$ This paper was presented at the International Scientific Conference "Law in the context of addressing the Challenges of the Contemporary World", held at the Faculty of Law, University of Niš, on $13^{\text {th }}-14^{\text {th }}$ April 2018.
} 


\section{Introduction}

The ownership right is an integral part of the right to property which, as a fundamental human right, has been guaranteed by the International agreements and the supreme national acts on human rights. At the international level, the warranting of the (private) property rights has been accompanied by numerous difficulties and incompliance, caused by ideological and political reasons. The debate, which was conducted in the process of internationalization of human rights among the advocates of maximalist ideas on private property and those who negated every need for its existence (Sprankling, 2014: 8-19), resulted in establishing the right to property, which is guaranteed in the International agreements as a qualified right - the right which is subject to various limitations, also including the possibility of deprivation of such right under certain conditions (Čok, 2004: 346). Due to disagreement in view of the property concept and the fear of certain states that, by warranting private property, they would be too restricted in the chance to accomplish their economic, political, social and other goals by limitation on property, this right was not guaranteed by the Treaty on Civil and Political Rights (1966), nor by the basic text of the European Convention for the Protection of Human Rights and Fundamental Freedoms (1950), ${ }^{1}$ but by the first Protocol to the European Convention, adopted in 1952 (Krstić, Marinković, 2016: 238-239).

Like in the past, the contemporary law also considers the ownership right, as the widest legal authority to hold, use and dispose of items, effecting everybody and ensuring to the title holder immediate and direct legal authority over the items (Kuštrimović, Kovačević, Lazić, 2009: 59). Although the ownership right belongs to the range of permanent, absolute and time-unlimited rights (Stanković, Orlić, 1999: 56), it has been limited ever since in many different ways. However, while in the past the purpose of limitations was primarily aimed at providing conditions for undisturbed use of items, through preventing abuses, banning the exceeded emissions, regulation of neighborly relations (etc.), in the contemporary law, the limitations on property ownership have been significantly

1 European Convention for the Protection of Human Rights and Fundamental Freedoms (hereinafter: "the European Convention" or "the Convention "), adopted on $4^{\text {th }}$ November 1950 in Rome, came into effect on 3 September 1953. Sweden and the United Kingdom were the loudest among the states which opposed introduction of the right to quiet enjoyment of property in the European Convention wording. On the other hand, Belgium, Italy, Holland and France were determined advocates of the idea on the necessity of guaranteeing this right, justifying their attitude by the fact that the property right is not the economic right only, but that it also has a political dimension, as a condition for individual independence and a basis for family stability. About the warranties of the property right contained in the European Convention, in more details: (Van Dijk, Van Hoof, 1989: 619-625; Peukert, 1981: 3238; Coban, 2004: 467; Gomien, 2000: 35-38). 
expanded and they are in the function of realizing numerous economic, political, social and other public interests of the community.

This paper examines the changes in the contents of constitutional matter on ownership right, within the context of social justice principles and social function of ownership right, as well as the principle of sustainable development as a long-term prospective of a community existence and advancement. In this paper, we analyzed and elaborated on several essential factors underlying the implementation of these principles in the domain of proprietary relations, on the example of the consititution of sixteen countries, including Serbia and some countries of former SFR Yugoslavia ${ }^{2}$, in an effort to establish contemporary trends in the constitutional standardization of contents, range and limitations on property ownership. Taking into consideration the constitutional changes at the beginning of the 20th century, related to the transformation of ownership, the right to property as a human right resulting from the constitutionalization of the social justice principle at the beginning of the 20th century, we try to establish if there is a challenge before the constitutions in the 21st century in terms of constitutionalization of the sustainable development principle, apart from the rule of law principle and the social justice principle, and how it would be reflected to property rights, at least. The encouragement for starting this research is the fact that issues relevant for the social and ecological functions of property ownership, gradually find the way in the constitutional matter and open the debate on whether to constitutionalize the sustainable development principle as a constitutional principle which is as important as the rule of law principle used to be in the 19 th century and the social justice principle in the 20th century.

\section{Social and ecological functions of property ownership in comparative constitutionality}

The principle of social function of property ownership is an expression of an endavour to establish the balance between the interest of an individual and the community needs, which implies establishing rules on how it is used. Viewed historically, the social function of property concept was articulated by León Duguit, the advocate of the sociological theory of law, who presented it to the professional public for the first time during the lecture in Buenos Aires in 1911. According to the concept posited by Duguit, property does not have "extenal"

2 The analysis includes the constitutions of the following countries: Austria, Belgium, Bulgaria, Danmark, Italy, Macedonia, Germany, Poland, Russia, Slovenia, Serbia, France, Croatia, Montenegro, Spain and Switzerland. Constitutional provisions of foreign countries are cited according to constitutional texts, as published on the portal Legislationline, Retrieved 15 May 2018 from http://www.legislationline.org /documents/section/constitutions. 
limits only, but also its "internal limits", immanent to its very nature. In contemporary law, the social function of property is not disputable, regardless of ideological starting points and principles of property regulation, being essentially different within national systems (Gregory, 2003: 733-776). In many states, the concept of social function of property ownership, was a justification for numerous agrarian and urban reforms (Foster, Bonilla, 2011: 101), which were the cornerstone for developing the social responsibility doctrine of the property right title holder. (Dagan, 2007: 1255-1274).

The social function of property ownership is related to the principle of social justice, which, apart from the principle of the rule of law, is warranteed by some constitutions as one of the basic principles on which the community rests. The essence of constitutional concretization of the social function of property ownership is embodied in two key rules: 1) property ownership implies obligations, and 2) using property ownership should serve the public interest. ${ }^{3}$ The right of the title holder to freely and at own discretion use (or not use) some real estates that belong to him/her, is subject to limitation by these rules, owing to the obligation imposed on him/her to use it in the way that contributes to the public wellbeing, including both to an individual person and the community. In some constitutions the mentioned limitation refers to all forms of property, ${ }^{4}$ in some of these consitutions it refers to public or state owned property only, economized and managed in the interest of citizens and the society, ${ }^{5}$ and there are also constitutions prescribing this limitation for private property only. ${ }^{6}$

In addition to the social function of property ownership, in certain constitutions it is recognized and for the first time expressly provided that the property ownership has the ecological function. ${ }^{7}$ The ecological function of property ownership stems from the right to a healthy living environment, which, as a fundamental human right $^{8}$ is nowadays warranted by a large number of consti-

3 Constitution of Germany (Art. 14, para.2)

4 Constitution of Germany (Art. 14, para.2), Constitution of Croatia (Art. 48, para.2), Constitution of Macedonia (Art. 30, paras.1 and 2), Constitution of Spain (Art.33, para.2 and Art. 128, para.1).

5 Constitution of Bulgaria (Art. 18, para.6).

6 Constitution of Italy (Art. 42, 2t. 2).

7 Constitution of Slovenia (Art. 61, para.1).

8 The right to sound environment is not a constituent part of the human rights corpus, guaranteed by European Convention on Human Rights. In practice of the European Court of Human Rights, its protection is achieved indirectly, by relating it to certain rights guaranteed by the Convention. The milestone in interpretation is the Decision in case Lopez Ostra against Spain, in which the European Court took the stand that not taking adequate measures to prevent further environment pollution and remove already made harm, represents human 
tutions. ${ }^{9}$ Shaping the very concept of ecological function of property ownership is the result of dramatic land, water and air polution levels which, in the second half of the 20th century, degraded natural ecosystems and human habitats and geopardized the biological survival and future of humankind. ${ }^{10}$ People recognized that, in case they did not set the limits on their technical and technological development, it would be done by the nature instead. This awareness caused intensified design and mechanisms building for suppression (control) of ecologically irresponsible behaviour and environmental protection, including some process instruments for resolving ecological disputes (Petrušić, 2004: 424).

Although versatile legal instruments were developed for environmental protection, no consensus is reached on whether a human is the central value they should protect, or it is the nature, as the value in itself. The anthropocentric concept of environmental protection is still dominant, implying protection for the purpose of creating living conditions and development of human kind. However, the impacts of the ecocentric concept are more and more powerful; based on the idea of equality of the human and the nature, this concept entails that nature represents a substantive value, regardless of its importance in terms of maintenance and development of human society (Rakić, 1995: 247). ${ }^{11}$

For the purpose of environment protection, constitutions provide numerous rights and obligatons of legal entities, like the right of everybody to receive true, timely and full information on the environment condition, ${ }^{12}$ the responsibility of

rights violation, justifying such attitude by the fact that «the state failed to establish the balance between the economic interest of the City of Lorca and the right of the Petitioner to effectively enjoy the right to home and privacy and family right, as anticipated by the Art. 8. of the Convention». Lopez-Ostra v. Spain, ECHR (1994), Series A, No. 303C. In more detail: (García San José, 2005: 12-15; Petrušić, 2005: 295-314).

9 Constitutions of Bulgaria (Art. 55, para.2), Montenegro (Art. 23, para.1), Croatia (Art. 69, para.1), Russia (Art. 62), Slovenia (Art. 72 para.1), Serbia (Art. 74, para.1), Spain (Art. 45, para.1).

10 In reports of the United Nations, it is estimated that throughout the world around 1.1 billion people have no access to drinking water, that more than five million people die per year due to diseases caused by polluted water, and each day six thousand children, less than five years old die due to the same reason. During one day only, six million tones of wastes are discharged into rivers, lakes and water flows. Information on the eco medium threat level in the country and the world may be found at the portal of the home eco-forum: http:// www.ekoforum.rs.

11 Nowadays, the ecocentric concept is in expansion, as confirmed by increasing number of those, advocating for the idea that the legal subjectivity is to be acknowledged for animals, as well (Stojanović, 2017: 10).

12 Constitutions of Montenegro (Art.23, para.2), Poland (Art.74, para.3), Russia (Art. 42) \& Serbia (Art.74, para.1). 
experts for hiding facts and circumstances which may represent a risk to human life and health, ${ }^{13}$ the obligation of everybody, particularly the public authorities to take care of, improve, reproduce and protect the environment, the live nature and its diversities, and use the natural wealth and resources ${ }^{14}$ in a reasonable way, the responsibility to protect the environment ${ }^{15}$ and compensate the damage made to environment, ${ }^{16}$ the right to impact the decision making on issues significant for environment protection, ${ }^{17}$ the right to healthy environment ${ }^{18}$, etc. ${ }^{19}$

For the purpose of nature preservation, as a precondition of sustainable development, constitutional solutions on responsibility (of public authorities, in the first place) towards future generations are significant. The fundamental values in constitutional systems are as follows: space design and humanization and upgrading and respect for the environment; ${ }^{20}$ the obligation of authorities to undertake activities in order to create permanent and measurable relation between the nature and its ability of renewal, on the one hamd, and its use by humans, on the other hand; ${ }^{21}$ the obligation of public authorities to exercise the policy which guarantees ecological safety to present and future generations; ${ }^{22}$ the responsibility towards future generations and obligation of the country to protect the natural wealth ${ }^{23}$ and the environment by implementing law enforcement and other measures.

The ecological function of property ownership is the basis for constitutional regulation of the use of natural resources (water, soil, mineral resources, etc.); the usage regime also includes limitation on property rights related to these resources, ${ }^{24}$ which is discussed in the fourth part of this paper.

13 Constitution of Russia (Art. 41, para.3).

14 Constitutions of Bulgaria (Art. 55), Montenegro (Art. 23, para.3), Croatia (Art. 69, para.2), Macedonia (Art. 43, paras.1\&2), Poland (Art.74, paras.2\&4 and Art.86), Russia (Art. 58), Slovenia (Art. 79, para.2), Serbia (Art.71, para.2).

15 E.g., Constitutions of Slovenia (Art. 72, para.3) and Serbia (Art. 74, para.2).

16 E.g., Constitution of Poland (Art. 86) and Constitution of Spain (Art. 45, para.3).

17 Constitution of Montenegro (Art. 23, para.2).

18 E.g., Constitution of Montenegro (Art. 23, para.2).

19 Some of these rights are the result of impelentation of United Nations Convention on Access to Information, Public Participation in Decision-Making and Access to Justice in Environmental Matters, as of 1998 (Aarhus Convention). More detailed (Todić, 2002: 185-191).

20 Constitution of Macedonia (Art. 8, para.1, lines 8 and 10).

21 Constitution of Switzerland (Art. 73).

22 Constitution of Poland (Art. 74, para.1).

23 Constitution of Germany (Art. 20a).

24 Constitutions of Croatia (Art. 52), Macedonia (Art. 55, para.3) and Russia (Art. 36, para.2). 


\section{Constitutionalization of the property rights - general constitutional guarantees on property rights, forms of property ownership and title holders of property rights}

As one of the basic (natural) rights, the inviolable right to property was guaranteed even by the end of the 18th century in the great declarations on human rights, but in the course of more than two centuries' long constitutionality development, it has been subject to significant changes in terms of its basic characteristics. Initially designed as a general standard, which guarantees the property right, the constitutional matter was expanded to numerous issues related to property and property rights. For that reason, the question we want to respond to in this paper requires the analysis of contemporary constitutional regulations on property rights.

In the comparative constitutionality, the general constitutional norm guarantees the right to property, ${ }^{25}$ private property and other forms of property ownership, explicitly prescribed by the law. ${ }^{26}$ Yet, the normative approach is different. In some constitutions, the ownership right is guaranteed in a separate provision, while the right of inheritance ${ }^{27}$ or other property rights ${ }^{28}$, that is, the right of inheritance ${ }^{29}$ and other property rights ${ }^{30}$ are guaranteed in another provision. Some constitutons contain just the blanket norm which guarantees the right to property, and the legislator is given freedom to regulate the right of inheritance, ${ }^{31}$ prescribe the limits of legal and testamentary inheritance and the right of the state to inheritance, ${ }^{32}$ or to guarantee the right of inheritance, prescribing that such right "may not be excluded or limited due to the non-fullfilment of public obligations. ${ }^{\text {" }} 3$ Some constitutions include specific constitutional solutions on stimulating savings aimed at acquisition of property rights on real estates (apar-

25 Constitution of Bulgaria (Art. 17. para.1), Montenegro (Art. 58 para.1), Danmark (Art. 1 para.73), France (Art. 2) and Art. 17 of the Decaration of Human and Citizens Rights (integral part of Constitution), Croatia (Art. 48 para.1), Italy (Art. 42 para.1), Switzerlannd (Art. 90 para.1).

26 Constitution of Russia (Art. 8 para.2).

27 Constitutions of Bulgaria (Art.17 para.1), Macedonia (Art.30 para.1), Poland (Art.64 para.1), Spain (Art.33 para.1).

28 Constitutions of Gemany (Art. 42 para.1), Poland (Art. 64 para.1), Serbia (Art. 58 para.1).

29 Constitutions of Montenegro (Art. 60), Croatia (Art. 48 para.4), Serbia (Art. 59).

30 Constitution of Russia (Art. 35 para.2).

31 Constitution of Slovenia (Art. 67 para.1).

32 Constitution of Italy (Art. 42, para.4).

33 Constitution of Serbia (Art. 59). 
tments and farmland ${ }^{34}$ and regulating property as the basis for management and decision making. ${ }^{35}$

Constitutions guarantee various forms of property ownership. Most constitutions guarantee the right to private and public property. ${ }^{36}$ Public property is defined in different ways: as state-owned property ${ }^{37}$ which includes municipality-owned property, ${ }^{38}$ the city-owned property, ${ }^{39}$ the property owned by an autonomous region, ${ }^{40}$ the community-owned property ${ }^{41}$ socially owned property ${ }_{12}^{42}$ or the national property ${ }^{43}$ Exceptionally, some constitutions guarantee cooperative property ${ }^{44}$ or mixed property ${ }^{45}$ as a special form of property. Several constitutions contain some specific solutions. The Constitution of France prescribes, for example, that "any estate, every enterprise, the use of which has or gains the character of national public service or, practically, monopoly, must become the property of the community “. ${ }^{46}$ The Constitution of Germany provides that "land possession, natural wealth and production means may be transferred to social property or some other form of social economy “. ${ }^{47}$ Regulating the way and the rate of indemnification for the purpose of socialization, the Constitu-

34 Constitution of Italy, the Art. 47 prescribes that «the Republic stimulates and protects savings in all their forms, disciplines, coordinates and controls the credit operations. Through savings, it assists in population's obtaining property over apartments, immediate property of farmland and and indirect and direct shareholding investments in big production complexes in the country. "

35 Constitution of Macedonia (Art. 58).

36 Constitutions of Bulgaria (Art. 17 para.2), Italy (Art. 42 para.1), Slovenia (Art. 70 para.1), Serbia (Art. 86 para.1).

37 Constitutions of Serbia (Art. 86 para.1), Spain (Art. 132 para.3).

38 Constitution of Bulgaria (Art. 17 para.4).

39 Constitution of Russia (čl 8. para.2).

40 Constitution of Serbia (Art. 86 para.1).

41 Constitution of France (para. 9 Preamble).

42 Constitution of Germany (Art.15).

43 Constitution of Spain (Art. 132 para.3).

44 Constitution of Serbia (Art. 86 para.1).

45 Constitution of Germany (Art. 87e, para.3) prescribes that „Railway lines of a federal state shall be considered as industrial enterprises in mixed ownership. They are the property of the federal state in case the business of such enterprise includes railways building and maintenance. The sales of state shares that it, according to point 2 , has got in that enterprise, is regulated by Law; most of shares shall remain the state property. More specific provisions shall be enacted by the federal law."

46 Constitution of France (para. 9 Preamble Constitutiona France).

47 Constitution of Germany (Art. 15). 
tion of Spain provides that the law "regulates the state property and national property, their management, protection and preservation". ${ }^{48}$ The Constitution of Poland provides that a family household is the basis of agricultural system of the country, as well as that such principle does not impair the right of property and inheritance, or the freedom of economy. ${ }^{49}$

Regarding the title holders of property, particularly in terms of ownership over real estates, the constitutional regulations refer to the status of foreign natural and legal persons as title holders of the ownership right. Constitutional solutions range betwen two extremes, starting from the universal guarantees on property rights to foreigners over real estates, with reference to legal regulations and ratified international agreements ${ }^{50}$, regulating the contents of the universal constitutional rule more specifically, and all the way to specifying the conditions under which foreigners acquire the ownership right, ${ }^{51}$ especially the ownership right over land, natural wealth and resources of general interest, ${ }^{52}$ or specifying resources over which the foreigners may acquire the ownership right ${ }^{53}$ and the possible range of their property rights..$^{54}$

\section{Constitutionalization of natural resources: property rights, usage regime and protection}

The constitutions which are subjected to this comparative analysis regulate the ownership right over the natural resources, as well as the regime of their use and special protection.

Constitutional regulations, in the domain of natural resources use and protection, are based on a widely accepted sustainable development principle aimed at meeting the needs of present generations, without endangering the ability

48 Constitution of Spain (Art. 132, para.3).

49 E.g., Constitution of Poland (Art. 23).

50 Constitution of Slovenia (Art. 68).

51 Constitutions of Montenegro (Art. 61), Croatia (Art. 48, para.3) Macedonia (Art. 31); Slovenia (Art. 68).

52 E.g. the Consitution of Bulgaria (Art. 22 para.1) prescribes that «Foreigners and foreign legal persons may not acquire the right property on land, except in case of inheritance according to the law. «

53 Constitutions of Slovenia (Art. 70, para. 3), Serbia (Art. 85, para.1).

54 Constitutions of Bulgaria (Art. 22 para.1) and Serbia (Art. 87 para.1) provide that "Foreigners may acquire concession right over the natural wealth and resources of general interest, as well as other rights, provided by law." 
of future generations to meet their own needs..$^{55}$ The essence of sustainable development is environment protection, ${ }^{56}$ which implies slowdown and eventual halting of natural resources depletion and environment degradation. ${ }^{57}$

Constitutional solutions in view of natural resources also differ. Some constitutions provide that these resources are the state property, ${ }^{58}$ i.e. owned by the community, ${ }^{59}$ or the private property; thus, they prescribe a special regime of their usage, possibility of expropriation ${ }^{60}$ and special conditions under which foreigners may acquire the ownership right over these resources and goods. ${ }^{61}$

Regarding the use of natural resources ${ }^{62}$ constitutions establish a special regime, by prescribing principles on which the usage of such resources rests (inalie-

55 The concept of sustainable development was proclaimed for the first time by UN Commission on Environment and Development, in a well-known Report «Our Common Future». Recommendations of this Report were adopted in Rio de Janeiro Summit in 1992 and they are contained in Agenda 21, which gives recommendations for sustainable management of land, water and forest resources in $21^{\text {st }}$ Century. During the last couple of years a new idea has been advocated for about, so called, „strong sustainability“, based on the fact that some parts of nature are non-renewable, therefore they should be preserved forever. Such an attitude became visible in the Report of the Environment Protection Commission „Environment and Human Rights", adopted in the Parliamentary Assembly of the Council of Europe in April 2003. (Environment and human rights, 2003).

56 Although there is not a full agreement on the normative contents of the notion "sustainable development", the theory points out to its elements, as follows: common but divisible responsibility, intergenerational solidarity, intragenerational solidarity, justice, participation and gender equality (Baker, 2006; 26). In literature, there may also be found different interpretations of the sustainable development principle. Thus, Jonathan M. Harris includes social inequality and environment pollution reduction in the principles of sustainable development (Harris, 2001: 21).

57 The National Strategy of sustainable development of Serbia (2008-2017), as of 2008 ("Official Gazette of RS», No. 57/2008) establishes the following principles of sustainable development: Intergenerational solidarity and intra- generational solidarity; Open and democratic society; Knowledge as the carrier of development; Inclusion in social processes; Integrating environmental issues in other sectors policies; Precaution; Subject causing pollution/ beneficiary pays; Sustainable production and consumption.

58 Constitutions of Bulgaria (Art. 18 para. 1), Montenegro (Art. 58 para. 3), Serbia (Art. 87 para.1).

59 Constitution of France (Art. 9 Preambule of Constitution).

60 Constitutions of Germany (Art. 15), Russia (Art. 36 para.2).

61 The Constitution of Slovenia - legal regulation of the right of foreigners to use natural wealth and resources in general use (Art. 80 para.3); the Constitution of Serbia - right of foreigners to acquire concession right over natural wealth and resources in general use (Art. 85 para.2) and the right of natural and legal persons to acquire certain rights on corresponding resources in general use, under conditions and in the way prescribed by law (Art. 87 para.2).

62 Constitution of Slovenia (Art. 70 para.1). 
nability, non-obsolence and non-seizure, banning the change of their intended purpose), ${ }^{63}$ as well as by regulating conditions under which these resources may be used, ${ }^{64}$ or the way they may be used.$^{65}$

There are significant differences among constitutions in view of the contents and the range of regulating natural resources, comprising air, water, land, mineral resorces, flora and fauna and the energy.

Air ${ }^{66}$ is a natural eco-medium in view of which various constitutions regulate various issues: establishing a unique boundary emmission values for the air harmful matters, ${ }^{67}$ air purification, ${ }^{68}$ air cleanliness maintenance, ${ }^{69}$ air space. ${ }^{70}$ In a smaller number of analyzed constitutions, air is recognized and explicitely specified as a resource significant for the environment, specifically protected.

Constitutions classify water as a significant natural resource, ${ }^{71}$ but there is a notable difference in the contents of constitutional provisions. Some constitutions, in addition to the blanket norm on water as a resource that enjoys special protection, ${ }^{72}$ place special emhasis on coastal beach area, ${ }^{73}$ the sea, sea-coast and islands. ${ }^{74}$ In other constitutions, there is a principal provision missing and there are specifically listed sea-coast,$^{75}$ coasts, beaches, territorial waters and

63 Constitution of Spain (Art. 131 para.1).

64 Constitutions of Russia (Art. 36 para.2), Slovenia (Art. 70 para.2), Serbia (Art. 87 para.3), Spain (Art. 132 para.1 and para. 3).

65 Constitution of Serbia (Art. 89 para.2) provides that „Law may limit the forms of using and disposing, that is, prescribes conditions for using and disposing in order to eliminate the risk of making harm to nature or to prevent the violation of the rights of other persons' interests, based on the law."

66 Constitutions of Austria (Art. 10, para.1, point 11), Germany (Art. 74, para. 1 point 24), Croatia (Art. 52).

67 Constitution of Austria (Art. 11, para.5).

68 Constitution of Germany (Art. 74, para.1 point 24).

69 Constitution of Austria (Art. 10, para.1, point 11).

70 Constitution of Croatia (Art. 52).

71 Constitutions of Bulgaria (Art. 18, para.1), Croatia (Art. 52), Germany (Art. 74, para.1, point 17 i Art. 91 a, para.1), Spain (Art. 132, para.2 i Art. 148, para.1, point 10), Switzerland (Art. 76).

72 Constitutions of Bulgaria (Art. 18, para. 1) and Croatia (Art. 52).

73 Constitution of Bulgaria (Art. 18, para.1).

74 Constitution of Croatia (Art. 52).

75 Constitution of Germany (Art. 74, para.1, point 17 and Art. 91a, para.1). 
natural springs ${ }^{76}$, land reclaimed from the sea and swamps ${ }^{77}$, chanels and irrigation, mineral and thermal water ${ }^{78}$, water resources ${ }^{79}$ and particularly the international and inter-cantonal water resources. ${ }^{80}$ Constitutions regulate other issues as well, significant for the water regime and preservation of this natural resource, such as: construction and use of hydraulic plants, ${ }^{81}$ careful use and protection of water sources and defense from harmful impacts of water, ${ }^{82}$ maintenance and discovery of water sources, using waters for energy production, cooling and intake in water flow circulation, ${ }^{83}$ enacting regulations on water protection, securing corresponding residual water, water quantities industry, securing embankmets and impact of atmospheric residues, ${ }^{84}$ competence of regional authorities related to water sources use and possibility of introducing taxes for water sources use, ${ }^{85}$ using water for transportation companies with tax payment for use, ${ }^{86}$ supply of water, ${ }^{87}$ marine waterways and river waterways of general significance, ${ }^{88}$ etc.

In a vast majority of constitutions, the land is recognized as the primary natural resource. ${ }^{89}$ The accent is on agricultural and arable land, particularly on the way of using this land, which is regulated in constitutions in different ways. Some constitutions put the emphasis on "rational and planned use"; 90 some insist on using the land "for agricultural purposes only, with the possibility to change the intended purpose of the land in exceptional cases only, if the need for that has been proved, under the condions and in the way prescribed by

76 Constitution of Spain (Art. 132, para.2).

77 Constitution of Belgium (Art. 113).

78 Constitution of Spain (Art. 148, para.1, point 10).

79 Constitution of Switzerland (Art. 76, para.1).

80 Constitution of Switzerland (Art. 76, para.5).

81 Constitution of Spain (Art. 148, para. 1, point 10).

82 Constitution of Switzerland (Art. 76, para.1).

83 Constitution of Switzerland (Art. 76, para.2).

84 Constitution of Switzerland (Art. 76, para.3).

85 Constitution of Switzerland (Art. 76, para.4). Italy (Art. 44 i Art. 117 para.2), Germany (Art. 75, para.1 points 3,4 \& 17), Poland (Art. 23), Russia (Art. 9, para.

86 Constitution of Switzerland (Art. 76, para.4).

87 Constitution of Germany (Art. 75, para.1, points 3 and 4).

88 Constitution of Germany (Art. 74, para.1, point 21).

89 Constitutions of Austria (Art. 14, st, 1, 2, 4 i 5), Belgium (Art. 113), Bulgaria (Art. 21), Croatia (Art. 52),2), Slovenia (Art. 71, paras.1 and 2), Serbia (Art. 88, para.1), Spain (Art. 47, para.1).

90 Constitution of Croatia (Art. 52). 
law. ${ }^{91}$ Some constitutions underline that usage must be "in accordance with the general interest, particularly if it is to do with the change of the land intended purpose"; $; 2$ some consitutions point out to "land design", 93 "agricultural structure improvement", ${ }^{44}$ while some prescribe the foundation of "regional institutions for crediting agriculture and land development. ${ }^{95}$ Some constitutions insist on agricultural and arable land protection, ${ }^{96}$ which is especially regulated in detail in the Constitution of Switzerland. ${ }^{97}$

In principle, certain constitutions provide that land is "the fundamental national wealth, under special protection of the state and the society", ${ }^{98}$ as well as that land is used and kept as "the basis of life and work of people living in a corresponding territory." ${ }^{\prime 99}$ The Constitution of Austria contains a specific solution, regulating in detail schooling of experts in the fields of agriculture and forestry. ${ }^{100}$

Constitutions regulate mineral (underground) resources as a significant natural and developmental resource, but the solutions differ and the terminology varies as well. Mineral resources or mining are explicitly mentioned in several constitutions only ${ }^{101}$ and most constitutions use general notions, the meaning of which is much broader, for example: natural wealth, ${ }^{102}$ natural resources, ${ }^{103}$ general interest resources, ${ }^{104}$ natural sources, ${ }^{105}$ natural heritage ${ }^{106}$, etc. The norms are, in most cases, general and include all natural resources. Regulation

91 Constitution of Bulgaria (Art. 21, para.2).

92 Constitution of Spain (Art. 47, para.1).

93 Constitution of Germany (Art. 75, para.1, points 3 and 4).

94 Constitution of Germany (Art. 91a para.1 point 3).

95 Constitution of Italy (Art. 114, para.2).

96 Constitutions of Austria (Art. 14, paras.1,2,4 and 5), Bulgaria (Art. 21), Germany (Art. 74, para.1, point 17), Poland (Art.23), Slovenia (Art.71, paras.1 and 2), Serbia (Art. 88, para.1), Spain (Art. 47, para.1 \& Art. 130, para.1).

97 Art. 104. Constitution of Switzerland.

98 Constitution of Bulgaria (Art. 21, para.1).

99 Constitution of Russia (Art. 9, para. 2).

100 Constitution of Austria (Art. 14, para. 1, 2, 4, i 5).

101 For example, in constitutions of Austria (Art. 10, para.1, point 10), Bulgaria (Art. 18, para.1), Croatia (Art. 52), Macedonia (Art. 56, para.1), Spain (Art. 45, para.2).

102 Constitutions of Macedonia (Art. 56, para.1), Slovenia (Art. 70, paras. 2 \& 3), Serbia (Art. 85, para.2).

103 Constitution of Russia (Art. 9 para.1).

104 Constitution of Serbia (Art. 88, para.1).

105 Constitution of Spain (Art. 45, para.2).

106 Constitution of Montenegro (Art. 78). 
on the use and protection of these resources in more specific details is missing, or referrence is made to legal regulation of these issues. ${ }^{107}$ The property regime and the way of using these resources is prescribed in a number of constitutions. ${ }^{108}$ Only some constitutions regulate the way of using these resources in more detail, with emphasis on the rational use, ${ }^{109}$ prescribing that such resources must be used to protect and improve living conditions and protect and renew the environment, ${ }^{110}$ that these resources may be freely disposed of, provided that it "would not harm the environment or disturb the rights and legal interests of other persons"111.

The subject of constitutional regulations is the protection of flora and fauna as well. Constitutional solutions vary, depending on the contents and scope of constitutional regulations, as well as the resources emphasized. Some constitutions, globally prescribe special protection of flora and fauna and other parts of nature, ${ }^{112}$ nature reserves ${ }^{113}$ and special ecosystems. ${ }^{114}$

In view of flora protection, some constitutions emphasize protection of specific parts, such as forests (special regime and forest protection, ${ }^{115}$ forests exploitation $^{116}$ ) and forest land, ${ }^{117}$ pastures, ${ }^{118}$ parks of national interest, ${ }^{119}$ mountain landscapes ${ }^{120}$ (special measures for mountain areas ${ }^{121}$ ), continental shelf (special exploration, excavation, use, preservation and economizing, taking care of biological, mineral and energetic resources in such marine vastness), ${ }^{122}$ footpaths

107 Constitutions of Slovenia (Art. 70, paras. 2 \& 3), Serbia (Art. 85, para.2).

108 E.g., Constitutions of Bulgaria (Art. 22 para.1), Montenegro (Art. 58 para.3 and Art. 59), Germany (Art. 15), Russia (Art. 36 para.2), Slovenia (Art. 70, para.3), Serbia (Art. 85, paras. $1 \& 2$ and Art. 87 paras. 1 \& 2), Spain (Art. 128 and Art. 131 para.1).

109 Constitution of Spain (Art. 45, para.2).

110 Constitution of Spain (Art. 45, para.2).

111 Constitution of Russia (Art. 36, para.2).

112 Constitutions of Croatia (Art. 52) and Macedonia (Art. 56, para. 1).

113 Constitution of Bulgaia (Art. 18, para.1).

114 Constitution of Italy (Art. 117, para.1).

115 Constitutions of Austria (Art. 10, para. 1, point 10), Bulgaria (Art. 18, para.1), Croatia (Art. 52), Germany (Art. 74, para.1, point 17), Switzerland (Art. 77).

116 Constitution of Spain (Art. 148, para. 1, point 8).

117 Constitution of Serbia (Art. 88 para. 1).

118 Constitution of Austria (Art. 10, para. 1, point 10).

119 Constitution of Bugaria (Art. 18, para.1).

120 Constitution of Spain (Art. 130, para.3).

121 Constitution of Italy (Art. 44).

122 Constitution of Bugaria (Art. 18, para.2). 
and walkways. ${ }^{123}$ Other consitutions regulate protecton of plants from diseases and pests, ${ }^{124}$ in particular, protection of agricultural and forest plants, ${ }^{125}$ sales of crops and plants, ${ }^{126}$ fertilizers for plants and protection devices, as well as acceptance and recognition of crops and plants kinds ${ }^{127}$, etc.

The subject matter of constitutional regulations is also the protection of fauna, but constitutional solutions differ. Thus, the regulated areas include: hunting and fishing activities, taking care of "preservation of abundance of fish, wild mammals and birds", ${ }^{128}$ fishing and hunting, ${ }^{129}$ particularly marine fishing, ${ }^{130}$ fishing in the open sea and along the coast, ${ }^{131}$ sales of animal food, ${ }^{132}$ taking measures against infectious and other diseases, dangerous for the community, both for people and animals, ${ }^{133}$ veterinary services and protection of animal food, ${ }^{134}$ protection of animals from torture, ${ }^{135}$ cattle breeding ${ }^{136}$, etc.

Energy and various sources of energy, as the natural and developmental resources, are also the subject matter of constitutional regulations, with particular reference to the rational use, production, transmission and distribution of energy, safety measures and strong currency tracks, construction plans and use of hydraulic plants, etc. ${ }^{137}$ There are specific provisions on the atomic energy

123 Constitution of Switzerland (Art. 88).

124 Constitutioni of Austria (Art. 12, para.1, point 4) and Germany (Art. 74, para.1, point 20).

125 Constitution of Germany (Art. 74, para.1, point 20).

126 Constitutioni of Austria (Art. 10, para.1, point 11) i Germany (Art. 11 a, para.1, point 20).

127 Constitution of Austria (Art. 10, para.1, point 11).

128 Constitution of Switzerland (Art. 79).

129 Constitution of Spain (Art. 130, para.1).

130 Constitution of Spain (Art. 149, para.1 point 19).

131 Constitution ofGermany (Art. 74, para.1, point 11).

132 Germany (Art. 11 a, para.1, point 20).

133 Constitution of Germany (Art. 11 a, para.1, point 19).

134 Constitution of Austria (Art. 10, para.1, point 11).

135 Constitution of Slovenia (Art. 72, para.4) and Consitution of Switzerland (Art. 80), prescribing the competence of Confederation to regulate «A. Keeping animals and caring about them; B. Animals experiments and interventions on live animals; C. Use of animals; D. Import of animals and animal products; E. Animals trade and transportation; F. Killing animals."

136 Constitution of Spain (Art. 130, para.1 and Art. 148, para.1, point 7).

137 Constitutions of Austria (Art. 10, para.1 points $9 \& 10$ and Art. 12, para.1), Italy (Art. 117, para.2), Switzerland (Art. 89 and Art. 91), Spain (Art. 45 and Art. 149, para.1 point 21), Germany (Art. 74, para.1, point 11a). 
as a source of energy, ${ }^{138}$ its production and use, strict prescription of using it for peaceful purposes, ${ }^{139}$ as well as the obligatons related to protection from risks incurred by atomic energy release or by ionized rays and removal of radioactive matters, etc. An illustrative example of detailed regulations in this field is offered by the Constitution of Switzerland. ${ }^{140}$

Constitutional regulations are not exhausted in identifying the most significant natural developmental resources only, but they expand to regulating fields which potentially endanger the environment. The subject matter of regulations are numerous issues related to production, sales, use and handling of matters and products that may endanger the living environment, such as: hazardous and other wastes management, ${ }^{141}$ pharmaceutical products production and handling, ${ }^{142}$ manufacture of radioactive products, weapons, explosive substances and matters ${ }^{143}$ with powerful biological effect, waste disposal, air purification and noise fighting, ${ }^{144}$ handling of medicaments and narcotic drugs, organisms, chemicals and objects that may impair health, ${ }^{145}$ establishing unique limit emission values for matters, harmful to air and air cleanliness maintenance, ${ }^{146}$ liquid or gaseous fuel or transportation of drive material, ${ }^{147}$ measures for preventing dangerous loading on environment, which occur by exceeding limit emmission values, ${ }^{148}$ regime of production, trade, keeping and using weapons and explosives, ${ }^{149}$ production, procurement, sales, import, export and passage of military material, ${ }^{150}$ food and control of food and provisions, ${ }^{151}$ meteorological service, ${ }^{152}$ special traffic regime of heavy vehicles for the purpose

138 Constitutions of Austria (Art. 10, para.1, points 10 \& 11), Bulgaria (Art. 18, para.4), Germany (Art. 74, para.1 point 11 a), Switzerland (Art. 90 and 118).

139 Constitution of Germany (Art. 74, para.1 point 11 a).

140 Constitution of Switzerland (Art. 89).

141 Constitution of Austria (Art. 10, para.1, point 11).

142 Constitution of Spain (Art. 163, para.1, point 16).

143 Constitution of Bulgaria (Art. 18, para.4).

144 Constitution of Germany (Art. 74, para.1 point 24)

145 Constitution of Switzerland (Art. 118)

146 Constitution of Austria (Art. 10, para. 1 point 11 and Art. 11, para.5).

147 Constitution of Switzerland (Art. 91).

148 Constitution of Austria (Art. 10, para.1, point 11).

149 Constitution of Spain (Art. 149, para.1 point 26).

150 Constitution of Switzerland (Art. 107, para.2).

151 Constitutions of Austria (Art. 10, para.1, point 11), Italy (Art. 117, para.2), Germany (Art. 74, para.1, point 20), Switzerland (Art. 104, page 3, point c).

152 Constitution of Spain (Art. 140, para.1 point 20) 
of environment protection, ${ }^{153}$ heavy vehicles traffic tax, ${ }^{154}$ road traffic effects related to environment and nature protection measures, ${ }^{155}$ environment protection from harmful effects of excessive use of fertilizers, chemicals and other auxilliary materials, ${ }^{156}$ control and supervision of regulations application, related to matters posing risk to environment ${ }^{157}$, etc.

Apart from identifying the development related natural resources, constitutions regulate resources protection as well. The most significant question is who is obliged to protect the environment, natural resources and wealth. There are no important differences among constitutions in regulating obligations related to environment protection, natural resources and wealth. In most cases, there are blanket provisions, such as "everybody is obliged to keep, take care of, and protect the environment, natural resources and wealth", ${ }^{158}$ simultaneously regulating the state (public authorities) obligation related to protection of the environment, natural resources and wealth. ${ }^{159}$ This issue is more precisely regulated in the provisions of federal and regional states constitutions allocating authorization among the various levels of authority. ${ }^{160}$

153 Constitution of Switzerland (Art. 84) regulates heavy vehicles transit traffic over the Alpes: «1. Confederation protects the Alpine area from transit traffic negative effects. It limits the transit traffic overload to a measure not harmful to people, animals and plants and living spaces, too. 2. Transit traffic of goods over the Alpes, from border to border, is by the railways. Federal Council enacts necessary measures. Exceptions are allowed only if they cannot be avoided. The Law must explain them in more detail. 3. Transit roads capacity in Alpine area must not be increased. This restriction excludes bypass roads, relieving settled places of transit traffic».

154 Constitution of Switzerland (Art. 85, para.1) establishes the right for introducing heavy vehicles traffic tax depending on their power and consumption.

155 Constitution of Switzerland (Art. 86, para.3 point d).

156 Constitution of Switzerland (Art. 104, para.3 point d).

157 Constitution of Austria (Art. 11 point 9) prescribes that «Federal government and some federal ministers have authorizations, as follows: 1 . Authority to get insight into the acts of Provincial authorities through the Federal organs; 2. Authority to request reports on application of law and ordinances enacted on the Federal level; 3.Authority to request all the information on implementation, necessary for preparation and enactment of Federal laws and ordinances; 4 . Autrofity to request information and insight into acts in some special cases, if it is necessary for applying other authorizations.»

158 E.g. Constitutions of Slovenia (Art. 73 para.1), Serbia (Art. 89 para.1).

159 E.g. Constitutions of Slovenia (Art. 73 para. 2), Serbia (Art. 89 para. 2), Spain (Art. 45, para. 2), Switzerland (Art. 74 para.2 and Art. 78)

160 E.g. Constitutions of Austria (Art. 10, 11 and 12), Italy (Art. 117), Germany (Art. 72, 74, 75, 87 c and 91 a), Spain (Art. 148 points 3, 7, 8, 9, and 10 and Art. 149 para.1 points 16, 19, 20, 21, 25 \& 26 and Art. 149 para.3), Switzerland (Art. 78 to 120). 
One form of protection is reflected in a type of legislation regulating the environment, natural resources and wealth protection. It is particularly visible in contries established on the federal and regional bases in which constitutions, carefully and in detail, regulate the allocation of authority among the central and non-central bodies, including both the basis and the framework of their responsibilities for the environment, natural and developmental resources protection. The most significant issues in this field are regulated by rules of the central authority bodies which have the legislative/regulatory authority. ${ }^{161}$ The regulation enforcement activities are vested in the central authority organs, ${ }^{162}$ or they can be reserved for non-central organs, too. ${ }^{163}$ Only in some fields of environmental protection, there is a competitive authority in the domain of legislation.Then, the central authority rules regulate the principles, essential and the most important issues, thus setting the general regulatory framework for the natural resources protection. As for the non-central organs, they are reserved the right to regulate some concrete issues more specifically within the provided frameworks.

A specific form of environment, natural wealth and resources protection is also the constitutional regulation of property rights on these resources and the title holders of such rights, including: forms of property (state propety, ${ }_{1}^{164}$ state monopoly, ${ }^{165}$ public property, socially owned property, private property ${ }^{166}$ ); titleholders of property rights (state property, ${ }^{167}$ state monopoly, ${ }^{168}$ public property, socially owned property, private property, ${ }_{169}^{169}$ property rights of foreign persons ${ }^{170}$ ); special regime of their use (legal regulation of the regime of using these resources, ${ }^{171}$ concession ${ }^{172}$ use and possibility of limiting property rights

161 Constitutions of Austria (Art. 10, 11 i 12), Italy (Art. 117), Germany (Art. 72, 74, 75, $87 \mathrm{c}$ and $91 \mathrm{a}$ ).

162 Constitution of Austria (Art. 10, para.1, points 9, 10,11)

163 Constitution of Austria (Art. 11, para.1, point 7 and paras.5 \& 9, as well as Art. 12, para.1, point 4)

164 Constitutions of Bulgaria (Art. 18, para.1), Russia (Art. 9 para.2)

165 Constitution of Bulgaria (Art. 18, para.2)

166 Constitution of Russia (Art. 9, para.2)

167 Constitutions of Bulgaria (Art. 18, para.1), Russia (Art. 9 para.2)

168 Constitution of Bulgaria (Art. 18, para.2)

169 Constitution of Russia (Art. 9, para.2)

170 Constitution of Bulgaria (Art. 22)

171 Constitution of Croatia (Art. 52, para.2)

172 Constitution of Bulgaria (Art. 18, para.5) 
on these resources, ${ }^{173}$ cautious and rational use of certain resources ${ }^{174}$ ); special protection of these resources ${ }^{175}$ and responsibility of the state, in the first place, ${ }^{176}$ but all other subjects as well. ${ }^{177}$

\section{Expropriation and limitations on the propety rights}

Social and ecological functions of property ownership are the bases for expropriation and limitations on the ownership right. Generally viewed, in comparative constitutionality, there are three prevailing approaches to regulating expropriation or limitations on private property. Some constitutions regulate expropriation only, ${ }^{178}$ other constitutions regulate expropriation and limitation on private property ownership in a uniform way, ${ }^{179}$ and the third group of constitutions include specific provisions on expropriation and limitation on private property ownership. ${ }^{180}$

\subsection{Expropriation - conditions under which it is possible and permissible}

In comparative constitutionality, solutions related to expropriation are characterized by some common features as well as by significant differences. The common features of constitutional solutions are related to the constitutional basis for expropriation, reasons and goals of expropriation, compensation for expropriated property, as well as the way and time of compensation payment for the expropriated property. Differences are reflected in the contents and range of constitutional regulation of issues relevant for expropriation. Differences are also visible in terms of legal regulation of expropriation; some constitutions prescribe that expropriation is allowed on the basis of law only, or if

173 Constitutions of Italy (Art. 44), Russia (Art. 36, paras. 2 \& 3)

174 Constitution of Switzerland (Art. 89) regulates the principles on the use of energy: «sufficient, manifold, safe, economic and ecological energy generating supply», «saving and rational enegry consumption», «using domestic renewable energies», «development of energy techniques, especially for energy saving and renewable energies», etc.

175 Constitution of Macedonia (Art. 56)

176 Constitutions of Croatia (Art. 52, para.1), Italy (Art. 9, para.2)

177 Constitution of Montenegro (Art. 78)

178 E.g. Constitutions of France (Art. 17 Declaration of Human and Civil Rights which is an integral part of the Constitution of France), Italy (Art. 42), Germany (Art. 14), Poland (Art. 21), Russia (Art. 35), Spain (Art. 33)

179 E.g.Constitutions of Montenegro (Art. 58 para.2), Croatia (Art. 50 para.1), Macedonia (Art. 30 paras. 3 \& 4), Slovenia (Art. 69), Serbia (Art. 58), Switzerland (Art. 26).

180 E.g.Constitutions of Poland (Art. 22), Serbia (Art. 58). 
it is provided by law, ${ }^{181}$ and some constitutions separately indicate that public interest, which is the basis of expropriation, ${ }^{182}$ must be established by law or by the way and range of expropriation. ${ }^{183}$ On the other hand, differences exist both in terms of reasons for expropriation and conditions that must be met for the expropriation to be legal. In constitutions, there are various conditions posed: public interest, ${ }^{184}$ state interest, ${ }^{185}$ common good ${ }^{186}$ public need, ${ }^{187}$ public benefit, ${ }^{188}$ social interest, ${ }^{189}$ inability to satisfying needs in other way. ${ }^{190}$ The terms used in constitutions are general, and their meaning and contents have not been specified; so, they equally seem to refer to the interests and needs of a widest range of citizens. As a good practice in comparative constitutionality, ${ }^{191}$ there are featured solutions ordering the legislator to operationalize and specify in detail the contents of the included terms.

One of expropriation conditions provided by national constitutions is indemnification of the property title holder. Constitutions mutually differ both in terms of principles, i.e. the criteria the indemnification is based on, and in terms of regulating the moment at which the property title holder is indemnified. One group of constitutions establish the principle of justice ("just indemnification", ${ }^{192}$ "just compensation"193), as the indemnification criterion. The second group of constitutions, alongside with the principle of justice, establish the market value as a principle for specifying the expropriated property compensation amount, thus also regulating more specifically the contents of justice principle

181 Bulgaria (Art. 17), Danmark (Art. 1 para.73), Croatia (Art. 50), Italy (Art. 42), Macedonia (Art. 30), Gemany (Art. 14), Spain (Art. 33), Slovenia (Art. 69), Serbia (Art. 58 para.2).

182 Constitution of Macedonia (Art. 30 paras. $3 \& 4$ ).

183 Constitution of Germany (Art. 14 para.2).

184 Constitutions of Montenegro (Art. 58 para.2), Macedonia (Art. 30 para.3), Poland (Art. 21 para.2), Serbia (Art. 58 para.2), Slovenia (Art. 69).

185 Constitution of Croatia (Art. 50 para.1)

186 Constitution of Germany provides that expropriation should „serve the common good“ (Art. 14 para.2).

187 Constitution of France provides that expropriation is allowed „when the public need requires that in a transparent way," (Art. 17 para.1 Declarations of civil freedoms and rights).

188 Constitution of Spain (Art. 33 para.3)

189 Constitution of Spain (Art. 33 para.3)

190 Constitution of Bulgaria (Art. 17, para.5).

191 E.g. Solutions in Constitutions of Germany and Macedonia.

192 Constitutions of Bulgaria (Art. 17, para.5); France (Art. 17, para.1 Declaration of freedoms and civil rights); Poland (Art. 21, para.2); Russia (Art. 35, para.3).

193 Constitution of Montenegro (Art. 58, para.2). 
("just compensation that may not be lower than market value"194) or explicitly establishing that expropriation is possible provided the compensation is paid at market value. ${ }^{195}$ The third group of constitutions is heterogeneous, including provisions which prescribe the payment of "corresponding compensation", 196 "full indemnification", 197 "full compensation", 198 "compensation with just estimation of community interests and the owner", 199 "compensation in kind or with indemnification. ${ }^{200}$ Only one of the analized constitutions prescribes that "private property may be expropriated even without compensation, if it is in common interest" 201 , as well as that "to the end of general benefit, law may provide that the right of possession of certain enterprises or groups of enterprises which refer to the basic public services or to the energy sources or have the monopolistic position, and the public interest ${ }^{202}$ prevails, may be kept for the state public bodies, or community of workers or an individual beneficiary, or it may be transferred to them by expropriation without compensation". Some constitutions even regulate the time for paying compensation for the expropriated property, providing that compensation is paid before the property expropriation. ${ }^{203}$ Only one of the analyzed constitutions specifies another expropriation condition, envisaging that it is possible only according to the decision of the court. ${ }^{204}$

Most constitutions contain the norm that proprietary and ownership rights enjoy equal legal protection. Exceptionally, only two of the analyzed constitutions regulate judicial protection of property right in expropriation proceedings, ${ }^{205}$ and

194 Constitutions of Macedonia (Art. 30, paras. 3 \& 4); Serbia (Art. 58, para.2).

195 Constitution of Croatia (Art. 50, para.1).

196 Constitution of Spain (Art. 33, para.3).

197 Constitution of Danmark (para.1 para.73).

198 Constitution of Switzerland (Art. 26, para.2).

199 Constitution of Germany (Art. 14, para.2) prescribes that «decision on expropriation must be enacted with just estimation of the community interests and the owner».

200 Constitution of Slovenia (Art. 69).. «

201 Constitution of Italy (Art. 42, para.3).

202 Constitution of Italy (Art. 43).

203 Constitutions of Bulgaria (Art. 17, para.5); France (Art. 17, para.1 Declaration of Freedoms and Civil Rights); Russia (Art. 35, para.3).

204 Constitution of Russia (Art. 35, para.3).

205 The Constitution of Danmark (Art. 3 para.73) prescribes that «any issue of expropriation acts legality and the indemnification amount may be brought before the Court. Proceedings of indemnification matters may be, according to the law, referred to courts, founded for that purpose»; the Constitution of Germany (Art. 14, para.3) prescribes that «in case of dispute for expropriation indemnification amount, jurisdiction of regular court shall prevai». 
only one constitution provides a special proceeding, which entails adopting a law which regulates expropriation, as a special form of property right ${ }^{206}$ protection.

\subsection{Limitation on the property ownership right: conditions under which the limitation is allowed}

In addition to expropriation, some constitutions regulate the possibility of imposing limitations on property ownership. Most constitutions which envisage this possibility regulate expropriation and limitation on property in the same way, particularly concerning the conditions under which expropriation and limitation on property are possible and allowed.$^{207}$ Only a smaller number of constitutions separately regulate limitation on property ownership, and conditions under which it is possible. In the comparative constitutionality, these conditions and formulations are different, such as: " ownership may be limited by law only", 208 "for the purpose of protection of the interests and security of the Republic, the nature, environment and health of people", 209 "ownership may be limited only to the extent which does not violate the essence of the ownership right", 210 "the way of property use may be limited", 211 "limitation on property ownership for the purpose of collection of tax and other levies or fines is allowed only in accordance with the law". 212

The consitutional solutions are also different when comes to the regulation of the way of using property ownership and compensation payment for limitations the title holders are subjected to. Limitations pertain to the use of natural resources (sea, sea coast and islands, water, air space, mineral resources and other natural wealth, land, forests, flora and fauna, other parts of nature), immovable estates and objects of special cultural, economic and ecological significance, enjoying the special protection of the state. ${ }^{213}$

206 The Constitution of Danmark (para.2 section 73) provides that «when adopting the Draft Law on Property Expropriation, 1/3 of the National Assmbly members may, within three days from the final Draft adoption, request that the proposal should not be submitted to the King for adoption until the new elections for the National Assembly be held, and the proposal accepted once again by by the newly constituted National Assembly».

207 Constitutions of Montenegro (Art. 58, para. 2); Macedonia (Art. 33 para. 3 i 4); Slovenia (Art. 69); Switzerland (Art. 26, para.2).

208 Constitutions of Croatia (Art. 50, para.2); Poland (Art. 22, para.3); Serbia (Art. 58, para.3).

209 Constitution of Croatia (Art. 50, para.2).

210 Constitution of Poland (Art. 22, para.3).

211 Constitution of Serbia (Art. 58, para.3).

212 Constitution of Serbia (Art. 58, para.4).

213 Constitution of Croatia (Article 52) 


\section{Concluding Remarks}

Contemporary constitutional solutions in the domain of proprietary relations are strongly impacted by the idea on the necessity to establish the balance between the individual interests of the property title holder and the community interests, but also the balance between the needs of present and future generations. Constitutional norms ensure the realization of social and ecological functions of property ownership. In the analyzed constitutions, the constitutionalization of the right to property clearly demonstrates the stance that property ownership entails obligations; therefore, it is subject to legitimate limitations, imposed to ensure not only the principles of social justice but also the principle of sustainable development, whose exercise is the cornerstone of survival and advancement of the humankind.

\section{References}

Baker, S. (2006) Sustainable development, New York: Routledge, London,

Coban, A. R. (2004), Protection of Property Rights Within the European Convention on Human Rights, Ashgate Pub Co.

Čok, V. (2004) Pravo na imovinu, u: Dimitrijević, V. i dr., Ljudska prava, Beogradski centar za ljudska prava, Dosije, 2004.

Dagan, H. The Social Responsibility of Ownership, 92 Cornell Law Review, 1255, Retrieved 15 May 2018 from http://scholarship.law.cornell.edu/clr/vol92/iss6/6

Environment and human rights (2003). Report, Committee on the Environment, Agriculture and Local and Regional Affairs, Rapporteur: Mrs Cristina Agudo, Spain, SOC, Doc. 9791, Parliamentary Assembly, Retrieved 15 May 2018 from https://assembly.coe.int/nw/xml/ XRef/X2H-Xref-ViewHTML. asp?FileID=10145\&lang=en

Foster, S.; Daniel, B. (2011) The Social Function of Property: A Comparative Law Perspective, Fordham Law Review, Vol. 80, p. 101, 2011; Fordham Law Legal Studies Research Paper No. 1960022, Retrieved 27 May 2018 from https://ssrn. com/abstract $=1960022$

García San José, D. (2005) Environmental protection and the European Convention on Human Rights, Strasbourg: Council of Europe.

Gomien, D. (2000) Short guide to the European Convention on Human Rights, Strasbourg: Council of Europe. 
Gregory S. A. (2003) Property as a Fundamental Constitutional Right - The German Example, 88 Cornell Law Review, 733, Retrieved 22 May 2018 from http:// scholarship.law.cornell.edu/clr/vol88/iss3/3

Harris, M. J. (2001) Basic Principle of Sustainable Development, Global Deevelopment and Environment Institute, WORKING PAPER 00-04, Tufts University. Retrieved 15 May 2018 from http://ase.tufts.edu/gdae/publications/working_papers/ Sustainable\%20Development.pdf

Kovačević-Kuštrimović, R.; Lazić, M. (2009) Stvarno pravo, Niš: Sven.

Krstić, I.; Marinković, T. (2016), Evropsko pravo ljudskih prava, Beograd: Savet Evrope

Legislationline, Retrieved 15 May 2018 from http://www.legislationline.org/ documents/ section/constitutions.

Petrušić, N (2004) Rešavanje ekoloških sporova pred Međunarodnim sudom za arbitražu i koncilijaciju u oblasti životne sredine, Pravni život. Tematski broj, Pravo i kulturne razlike. Tom 1, br. 9.

Petrušić, N. (2005) Ograničenja prava svojine iz javnih interesa -praksa Evropskog suda za ljudska prava, u: Pravni sistem Republike Serbia - usaglašavanje sa pravom Evropske unije, Niš, Pravni fakultet.

Peukert, W. (1981) Protection of Ownership under Article 1 of the First Protocol to the European Convention on Human Rights, Human Rights Law Journal, No. 12.

Rakić, V. (1995), Ekološko pravo kao pravo čoveka, Pravni život, 9/95.

Sprankling, J.G. (2014) The international law of property, Oxford, New York: Oxford University Press

Stanković, O.; Orlić, M. (1999), Stvarno pravo, Beograd.

Stojanović, N. (2017) Prvo životinja, Niš: Centar za publikacije.

Todić, D. (2001) Učešće javnosti u zaštiti životne sredine, međunarodno i unutrašnje pravo, Pravni život, Tom prvi, br. 9.

Van Dijk, P.; Van Hoof, G. J. H. (1998) Theory and Practice of European Convention on Human Rights, London: Kluwer Law Int. 


\author{
Др Маријана Пајванчић \\ Редовни професор (у пензији) \\ Правног факултета Универзитета у Новом Саду \\ Др Невена Петрушић, \\ Редовни професор \\ Правни факултет Универзитета у Нишу
}

\title{
СОЦИЈАЛНА ФУНКЦИЈА СВОЈИНЕ У КОНТЕКСТУ ОДРЖИВОГ РАЗВОЈА
}

\begin{abstract}
Резиме
У раду се истражује садржај права својине као људског права, с ослонцем на компаративну уставност, међународне стандарде у овој области, праксу Европског суда за људска права и решења садржана у Уставу Републике Србије. У фокусу је контитуционализација права својине у контексту принципа социјалне правде и социјалне функције права својине, као и принципа одрживог развоја. Елаборирано је неколико кључних питања која су од значаја за остваривање ових принципа.
\end{abstract}

Размотрен је својински режим над развојним ресурсима и добрима у општој употреби, а нарочито статус страних физичких или правних лища као титулара својине, посебан режим коришћења ових добара, посебна заштита добара која чине развојне ресурсе и др. Анализирана су могућа ограничењима права својине, при чему је посебна пажња посвећена експропријацији, условима под којима је она могућа и допуштена, основима за експропријацију (јавни интерес, заштита животне средине и др.), принципи на којима почива одређивање накнаде за експроприсану својину (правична накнада, накнада на основу тржишне вредности) и начин исплате накнаде (претходна или накнадна) и посебно заштита права својине у поступку експропријације (судска заштита).

Размотрена су уставна решења у погледу начина коришћења права својине посебно режими коришћења добара која чине развојне ресурсе (пољопривредно земљиште, шуме, пашњаци, рудна богатства и др.), коришћење добара у контексту социјалне функције власништва, јавног интереса, екологије и заштите животне средине сл. Сагледана је и расподела надлежности између различитих нивоа власти у федералним и регионално уређеним државама у вези са регулисањем својинских права (регулативе, извршење, одговорност и др.), као индикатор одговорности различитих нивоа власти у домену коришћења својинских права и развојних ресурса у заједници.

Кључне речи: Право својине, социјалне функције права својине, ограничења права својине, одрживи развој. 
